УДК $811.342 .2+811.512 .1$

DOI: 10.33184/YVDK-2021-04-30.27

Ф.Р. Латыпов (доц. УГАТУ, г. Уфа)

\title{
ОСОБЕННОСТИ СТИЛЯ ИЗЛОЖЕНИЯ И АРХИТЕКТУРНО-СТРОИТЕЛЬНЫЕ ТЕРМИНЫ В ИБРИЙСКОЙ ЭПИТАФИИ НА КАМЕННОЙ СТЕЛЕ ИЗ СИНАРКАСА
}

\begin{abstract}
В статье рассматривается иберийская надпись на каменной стеле из Синаркаса. Выполнены транслитерация знаков надписи, разбивка ее на отдельные слова, осуществлен дословный перевод на основе метода ПЭКФОС. Отмечена специифика выбранного стиля изложения этой изученной эпитафии, перечислены архитектурно-строительные термины, обнаруженные в тексте и находящие соответствия в языках, родственных иберийскому.

Ключевые слова: иберийская эпитафия, метод дешифровки ПЭКФОС, тюркские языки, архитектурно-строительные термины.
\end{abstract}

This paper treats an Iberian inscription placed on the funeral stone stele from Sinarcas. The research includes transliteration of the signs in the inscription, splitting the text into words and word-for-word translation using the CECAPE deciphering method (consecutive etymological and combinatorial approximation with phonetic feedback). Consideration is given to peculiar features of the style of presentation chosen for the epitaph in question. A list is composed to cover architectural and construction terminology found 
in the text with parallels in the languages allied to Iberian.

Key words: Iberian epitaph, CECAPE deciphering method, Turkic languages, architectural and construction terminology.

В письменах древнего населения Пиренейского полуострова представлена важная информация для понимания ранней истории и становления культуры всей Европы. В постледниковый период (с VIII тыс. до н.э.), как показывают палеоисследования раннего генофонда популяций Европы [10], ее заселение происходило несколькими волнами полукочевых, неиндоевропейских по языку, племен Малой Азии, Ближнего Востока и степей нынешней Украины $[4,5,11]$.

Пришедшие из Сибири во второйө половине II тыс. до н.э. индоевропейские племена (протогреки в XIII в. до н.э., кельты в VIII в. до н.э.) переняли многие элементы культуры, мифологии и письменности местных племен. Поэтому, изучая письмена наиболее раннего населения Европы, можно многое узнать о тенденциях культурно-исторического развития Европейского континента в давние времена (без тенденциозных искажений, принятых в историографии классических цивилизаций античности).

По языкам и культуре древнего неиндоевропейского населения Испании, в 2016 и 2019 гг. у нас вышли две монографии и множество публикаций в научной печати. В них рассматривались иберийские надписи на металлических пластинах, на бытовой посуде, на установленных в местах захоронений стелах $[4,6,11,12]$. Среди надмогильных стел особое внимание было обращено на эпитафии, где надписи закручивались по спирали (Хардаде-де-Абобад, Сан-Перпетуа-деМогода, Фонте-Велье [4]).

В 2015 году наше внимание привлекла надмогильная плита из Синаркаса (надпись на ней получила условное обозначение Sinarcas I [12]). Надпись выполнена в южно-левантийской системе полу-алфавитного иберийского письма [11]. В ее верхней правой части начертаны пять крупных знаков, напоминающих римские цифры. На рисунке мы приводим фоторепродукцию 
лицевой стороны стелы из Синаркаса, взятую из книги Бенжамена Инарейхоса Колладо (11], с. 224):

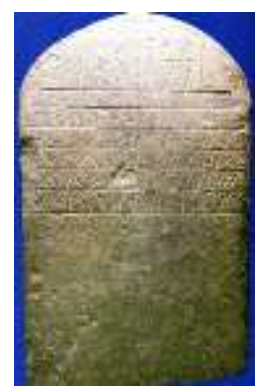

Рис. Фоторепродукция лицевой стороны стелы из Синаркаса ([11], с. 224).

По представленному рисунку видно, что многие знаки по краям этой каменной плиты заметно стерлись. В 2015 году это обстоятельство нас несколько притормозило, так как требовалось тщательное изучение плохо различимых знаков надписи для их более надежной идентификации. В 2018 году, будучи в Испании мы посетили Музей предыстории Валенсии, где непосредственно изучили поверхность исследуемой стелы и выслушали мнение испанских коллег (см. Textos ibericos [12]) по идентификации всех знаков стелы.

Используя свой многолетний опыт разбивки иберийских текстов на отдельные слова (нами изучено более 40 протяженных иберийских текстов [4], [6]), мы произвели лексемную разбивку текста Синакаса по всем ее семи строкам.

Далее, применяя метод дешифровки ПЭКФОС [3] и используя всю базу данных по переведенным ранее иберийским текстам $[4,6]$, мы получили литературный перевод этой эпитафии на русский язык:

1. Место погребенья (нашего товарища ?) (msge) (того, на котором сфокусирован настоящий интерес и чья могила помечена этим знаком (стелой); (ему было) 2+5+5+50 (62 года).

2. $\mathrm{OH}$ (bai) был нашим молочным братом (set-aś) (сотрапезником? нашим 60-ти летним ровесником ?), (к тому 
же) активным сплотителем страны (il-dut-aś) (организатором? защитником?), опорой (eba[nei]).

3. Его ([a]n) мы (wi) (считали) прирожденным конструкторомпроектировщиком (seltar) (архитектором, зодчим), строителем зданий (banwi),

4. единственным в своем роде (beŕ bein) зодчим-великим строителем (arieugia),

5. одной из главных опор (cauec-aś) наших родов (rwi), счастливым подарком судьбы (tal-oite).

6. Дорогой, почитаемый (cari) наш великий (-ar) зодчий (eugiar), архитектор (seltar),

7. строитель зданий (banwi)! Твой образ (профиль головы basi, черты лица) будет светить всегда balcar (в нашей памяти). Любящие (wbaŕ), мы (wi).

Наш перевод этого текста на испанский язык получился таким:

1. El lugar de entierro (¿de nuestro camarada?) (msge) (sobre quién hay un realmente enfocado interés y cuya tumba está marcada con este signo ó símbolo (conestela)); (él tenía) $2+5+5+50$ (62 años).

2. Él (bai) era nuestro hermano deleche ó amamantamiento (set-aś) (¿con quién compartiamos las comidas? igualmente sesentañero?), (además) un activo luchador por la unidad del país (il-dut-aś) (¿un organizador? ¿undefensor?), unbastión (eba[nei]).

3. Él ([a]n) por nosotros (wi) (considerado) un diseñador-constructor nato (seltar) (arquitecto, máximo responsable de una obra), constructor de edificaciones (banwi),

4. el único de su género (beŕ bein) máximo responsable de una obraconstructor jefe (ari eugia),

5. como uno de los principales baluartes (cauec-aś) de nuestros géneros (rwi), un regalo de suerte del destino (tal-oite).

6. Querido, venerado (cari) nuestro gran (-ar) máximo responsable de la obra (eugi-ar), arquitecto (seltar), constructor profesional que se encarga de proyectar, diseñar, dirigir la construcción y el mantenimiento de edificios, urbanizaciones, ciudades y estructuras de diverso tipo- 
7. (banwi) ! Tu imagen (perfil de la cabeza basi, rasgos faciales) brillarán balcar (en nuestra memoria y recuerdos). Amantes o queridos (wbaŕ), nosotros (wi).

При переводе текста Sinsrcas I нами были использованы следующие этимологические привязки из ранее переведенных иберийских текстов [4], [6], релеванты из родственного иберийскому этрусского языка [3], из западно-тюркских и древних восточно-семитских язвков [9]:

a) из ранее переведенных иберийских текстов [4, 6-8]:

bas «голова», balc- «светить, блестать», wba- «любить, целовать», bina/bena/banw «здание», beŕ «один», ebana «опора», bai «он», wi «мы», $\mathbf{n = [ a ] n [ e ] ~ ( э т р у с с к . ~ a n e ~ « е г о » ) ; ~}$

б) по соответствующим релевантам из этрусского языка:

set «молоко», epana «опора, центр внимания» [3], dutэтрусск. Өut- «держать», caŕi (семит.) этрусск. ceri, cerixunce «почитаемый, дорогой»,

eugia «строитель» этрусск. еu- «нагромождать, складывать кверху, строить», eurat «постамент» (первое слово в тексте столбика «чеппо» из Перуджи (CIE 4538)), rw «род» этрусск. reux «род» (TLE 1, [2]), казан.-тюрк. о̆ru «род»;

в) из восточно-семитских языков, заимствованных еще во времена проживания предков иберов в Восточном Средиземноморье:

ms - mäšhad «место погребенья», mäšüb «смешанный, сопричастный к делам, товарищ», mäšgul' «занятый делом», selta «повод, заложенная изначально идея, причина, проект», казан.тюрк. syltau «повод», cauec cavaim «столбы, подпорки», tal-, talig «счастливая судьба, доля» [9].

\section{Особенности стиля изложения эпитафии на стеле Синаркаса}

Стиль изложения эпитафии из Синаркаса имеет свои особенности, отличающие ее от других близких по времени написания эпитафий Западного Средиземноморья, в частности, по очередности изложения:

Этрусские (VI - III вв. до н.э.) [3] обычно включают: 
- имя покойного (-ницы), его (ее) предки по мужской линии;

- какие профессиональные качества он развил при жизни (или какой она красавицей өesanteia и заботливой была при жизни): стал мастером zivas, царем zilc, образцовым мужем puiac, славным воином өanlu ratnaś);

- какие благие дела он творил при жизни, кому покровительствовал;

- пожелания богам позаботиться о покойном «на том свете»;

- пожелания богам оказать милость оставшимся «на этом свете (muni svlet)» родственникам покойного (-ницы);

Иберийские (V - I вв. до н.э.) [2-3] обычно включают:

- некую информацию об усопшем (без указания его имени), сожаления о приостановке процесса развития личности усопшего «в этом мире»;

- пожелания по взаимоотношению усопшего с Богом «на небесах».

На стеле из Синаркаса, в иберийской традиции, не указано имя усопшего, но как у этрусков отмечаются высокие творческие и родственно-корпаративно-товарищские качества умершего архитектора-строителя. Удивительным является то, что, несмотря на высокий уровень религиозности иберов, в эпитафии нет ни одного упоминания Бога Tin. Все положительные качества покойного зодчего рассматриваются не как дар Бога, а лишь как «счастливый подарок судьбы» (tal-oite).

\section{Архитектурно-строительные термины}

Их три в рассматриваемой эпитафии и они расширяют наши познания в области профессиональной терминологии в пратюркских языках Западного Средиземноморья. В данном случае речь идет о лексемах seltar «проектировщик зданий, apхитектор», eugiar «зодчий»,

banwi «строитель зданий». Из ранее изученных этрусских текстов («Tavola di Cortona», TLE 1 и др. [1, 3]) нами уже были выделены и идентифицированы такие, связанные со строительством зданий термины, как: tars «стиль, манера 
строительства», minaś «архитектура», lais «проект», inpa

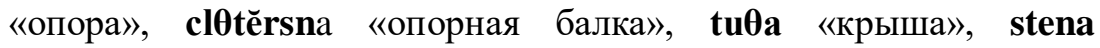
«стена», fratuc «наружная поверхность», eu turannuve «стройненькое здание», lisai «обсуждение (проекта)».

Здесь интересным является то, что все эти термины активно использовались в дореволюционном казанско-тюркском языке, но в 1920-ые годы в молодой Советской России были вытеснены из большинства тюркских языков (якобы они были арабскими заимствованиями, приобретенными в период господства ислама) и заменены (как и в русском языке) на западноевропейские термины, искусственно воссозданные на греческой, латинской и немецкой корневой основе. Таким образом, казанско-тюркский язык потерял значительный пласт своей древней ближневосточной терминологии, успешно до этого использовавшейся на протяжении 3 тыс. лет

\section{ЛИТЕРАТУРА \\ 1. Латыпов Ф.Р. Уникальное словосочетание celtinĕitisś tarsminaśś и другие сложносоставные понятия, термины архитектурно-строительного, гидротехнического и технологического планов в этрусских текстах //Проблемы востоковедения, 2010. № 2. - C. 121-126.}

2. Латыпов Ф.Р. Взаимосвязь субъектов траурного события в текстах этрусских эпитафий // Проблемы востоковедения, 2011. № 1. - С. 67-72.

3. Латыпов Ф.Р. Общие сведения, основные группы слов и дословные переводы крупнейших этрусских текстов на русский, английский и итальянский языки. - Уфа: Полиграфдизайн, 2014. - 152 с.

4. Латыпов Ф.Р. Иберийские языки Древней Испании - результат ускоренного фонетического развития некоторых пратюркских языков Западного Средиземноморья. - Уфа: Полиграфдизайн, 2016. $152 \mathrm{c}$.

5. Латыпов Ф.Р. На западных границах пратюркской ойкумены: Туман-ный Альбион от каменного века 
до раннего средневековья. - Уфа:Полиграфдизайн, 2017. - $100 \mathrm{c}$.

6. Латыпов Ф.Р. Элементы этнопедагогики иберов, нашедшие отражение в надписях на свинцовых пластинах и в граффити на поверхностях декорированных ваз. - Уфа: Полиграфдизайн, 2019. - 136 c.

7. Латыпов Ф.Р. Письменное наследие древних тарков Средиземноморья: Восток на Западе // Сб. науч. статей конф.: Диалог культур Востока и Запада через призму единства и многообразия в преемственности и модернизации общественного сознания: Древний мир, Средневековье, Новое и Новейшее время. - Алматы, Екатеринбург: Институт востоковедения им. Р.Б. Сулейменова КН МОиН Респ. Казахстан, 2020. С. 7-16.

8. Латыпов Ф.Р. Из письменного наследия древнейших неиндоевропейских народов Европы: три иберийских письма-призыва на свинцовых пластинах из Испанского Леванта // Матер. III Всеросс.науч.-практич. конф. (с междунар. участием): Диалог культур в глобализирующемся мире. - Махачкала: АЛЕФ, 2020. - С. 27-30.

9. Хамзин К.3., Махмутов М.И., Сайфуллин Г.Ш. Арабско-татарско-русский словарь. - Казань: Таккнигиздат, 1965. - 865 с.

10. Burger J., Kirchner M., Bramanti B., Haak W., Thomas MG. Absence of the lactase-persistenceassociated alleale in early Neolithic Europeans // Proc.

11. Natl. Acad. Scien. USA, 2007. 104. - P. 3736-3741. Hinarejos Benjamín Collado. Los íberos y su mundo. - Madrid: Ediciones Akal, S.A., 2014. - 269 p. Textos ibericos del Museo de Prehistoria de Valencia, serie de trabajos varios, num 81. - Valencia: Diputacion provincial de Valencia, 1985. - 131p.

(C) Латыпов Ф.P., 2021 г. 